\title{
comentarios bibliográficos
}

\section{La fiesta es algo muy serio... "Palabra" de Rosario Camacho}

M. ${ }^{\mathrm{a}}$ José de la Torre Molina y Reyes Escalera Pérez

Universidad de Málaga

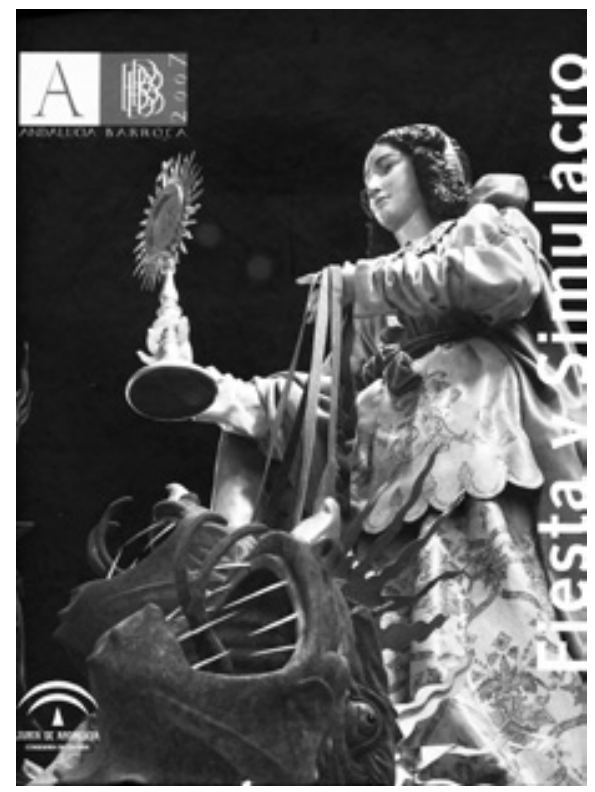

Este número del Boletín de Arte dedicado a Rosario Camacho nos ha recordado a todos, compañeros, amigos y discípulos, la trayectoria profesional y personal de esta infatigable investigadora. Hemos podido comprobar que ha sido pionera en numerosos campos y sí, también lo ha sido en el estudio de la fiesta del Barroco y su repercusión en las celebraciones decimonónicas. En 1988 vio la luz su primera aportación en la revista Jábega $\left(n{ }^{\circ} 62\right.$, pp. 39-51), en la que estudió la estancia de
Isabel II en nuestra ciudad en octubre de 1862, trabajo que amplió con el análisis de las celebraciones que también se organizaron en Murcia en la "Introducción» del facsímil de Ramón Franquelo, La Reina en Málaga... (1991, pp. II-XL) delicioso libro que evoca los actos que se organizaron para agasajar a la soberana y describe las arquitecturas efímeras que se levantaron para tal fin. Unos años después, en 1994, la reina Isabel vuelve a ser protagonista, junto a M. ${ }^{a}$ Luisa Fernanda, de una nueva investigación publicada en el Boletín de Arte (n. ${ }^{\circ} 15$, pp. 189-208). En esta ocasión la doctora Camacho aborda los festejos que organizaron las ciudades de Madrid y Málaga para solemnizar la boda de ambas hermanas, ceremonia que tuvo lugar el 10 de octubre de 1843. En la capital, engalanada majestuosamente como le correspondía, el regocijo duró cuatro días y poco tiempo después Málaga lo celebró con un Te Deum en la catedral y diversas funciones que tuvieron lugar en la plaza mayor, adornándose algunos de sus más vetustos edificios con colgaduras, doseles, imágenes y luminarias, disponiendo en ellos textos y divisas que hacían patente el sen- 
tir de los malagueños hacia la soberana al mismo tiempo que evocaban la riqueza y la modernidad de la ciudad.

Estas efemérides regias decimonónicas se celebraban con aparatos y componentes inherentes a las festividades del barroco: luces, fuegos de artificio, juegos de cañas, toros, solemnidades religiosas, lujosas comidas, arquitecturas y adornos de quitaipón... en definitiva simulacro y apariencia, deseo de ostentación y voluntad de atrapar al espectador con dispositivos extraordinarios y medios vistosos. Lo mejor para el rey... Así debió entenderlo el VIII duque de Medinasidonia cuando en 1624 organizó la estancia en sus dominios del joven Felipe IV en su visita a Andalucía, fastos y agasajos que desgrana la profesora Camacho en un trabajo de sugestivo título: "Felipe IV en el Bosque de Doñana: un viaje regio, un banquete espléndido, un respetuoso homenaje, una amistad del alma" (Congreso Internacional Andalucía Barroca. Actas II Historia demográfica, Económica y Social, 2009, pp. 249-257).

Igualmente significativas e influyentes han sido sus aportaciones al estudio de la fiesta en el siglo XVIII. Ya desde principios de la década de 1990, la profesora Camacho fue una de las artífices del interés que las celebraciones públicas hispanas del siglo XVIII empezaron a suscitar entre los historiadores de las artes y de la revisión del tópico, muy extendido hasta ese momento, de que las fiestas de esa centuria y de la siguiente representaban una prolongación decadente $-y$ fuera de contexto- de los grandes fastos y fórmulas festivas del siglo XVII.

Este cambio de perspectiva queda claramente de manifiesto en su trabajo «Fiestas por la proclamación de Carlos IV", publicado en el volumen España Festejante. El siglo XVIII (2000, pp. 495-504), una revisión de investigaciones anteriores -suyas y de otros autores- al que añadió aportaciones propias e inéditas sobre fiestas poco conocidas. También destacó en este estudio la diversidad de fórmulas celebrativas empleadas en las distintas urbes y su adaptación a los requerimientos impuestos por circunstancias diversas, en un marco festivo -las proclamaciones regias- que a menudo ha sido erróneamente considerado como una realidad homogénea.

La revisión de algunos principios asumidos acríticamente y su compromiso con la renovación historiográfica son características que permean todos los trabajos de la profesora Camacho sobre las fiestas del setecientos. Por ejemplo, en su artículo sobre los "Aleluias" de la Catedral de Málaga -publicado en los Cuadernos de Arte e Iconografía en 1993 (pp. 357-367) y posteriormente recogido en el Boletín de Arte (1995, n. ${ }^{\circ} 16$, pp. 187-206)- desestabiliza la tradicional formulación 
de los conceptos "culto" y "popular" como integrantes de un binomio jerarquizado y excluyente. A través del estudio de las estampas "Aleluias" de la Catedral de Málaga, repartidas entre los fieles con motivo de la Pascua de Resurrección, destacó la conexión entre una y otra instancia, así como la pluralidad de realidades existentes en el seno de ellas. Además de analizar los recursos iconográficos empleados y sus orígenes, profundizó en las distintas capas de significado que estas estampas contenían, la relación entre ellas, los veneros de religiosidad contrarreformista que las alimentaron y su posible nivel de comprensión y recepción por parte de distintos estamentos.

Otro gran trabajo sobre la fiesta religiosa del siglo XVIII, en el que se exploran las interrelaciones entre las fórmulas de religiosidad popular y culta en el marco de la fiesta institucional, fue su introducción al estudio sobre la celebración de la festividad de San Ciriaco y Santa Paula, en la Málaga de 1777. La trascendencia de este trabajo, publicado en 1995, ha sido enorme. Y no solo en nuestro círculo profesional: Nos atrevemos a afirmar que la reactualización que está viviendo la festividad local de San Ciriaco y Santa Paula en la ciudad de Málaga y el interés por los recursos empleados en su celebración en el pasado no podrían entenderse sin esta publicación, que es un magnífico ejemplo de la responsabili- dad que los historiadores tenemos en la construcción y en la redefinición de las identidades colectivas.

La profesora Camacho no solo estudió grandes eventos. También fue coartífice de uno de los mayores que ha vivido la ciudad de Málaga en los últimos años: La exposición que dirigió, junto a la profesora Reyes Escalera, Fiesta y Simulacro (2007), en el marco del macroproyecto Andalucía Barroca. El Catálogo de la exposición da una idea de la magnitud y de la relevancia de esta muestra: Siete capítulos escritos por especialistas en celebraciones públicas y seis fichas de catálogo de obras artísticas de gran nivel y de naturaleza muy diversa. Tesoros -a veces en el sentido literal del término- habitualmente de imposible acceso para el público general. Con el permiso de la profesora Escalera, referiré aquí una anécdota que siempre recuerdo cuando se alude a esta exposición: El momento en el que las dos responsables de la misma me pidieron que escribiese uno de los capítulos del Catálogo y asesoramiento para la inclusión de instrumentos musicales en la muestra. Lo menciono aquí porque este interés expresa de manera inequívoca el espíritu científico y el sentido crítico de los estudios de la profesora Camacho: Pese a su enorme presencia en las celebraciones públicas de raigambre barroca, la música -y lo sonoro en general- eran en ese momento una realidad poco 
contemplada en los estudios festivos en España. Sin embargo, tanto Charo como Reyes supieron ver la necesidad de dar un lugar relevante a la música en un proyecto que, desde el principio, se planteó -como ellas tantas veces han defendido que es necesario hacer en las investigaciones sobre fiesta- no solo desde la interdisciplinariedad, sino desde la transdisciplinariedad. $Y$ entendieron la potencialidad de combinar las perspectivas sobre el fenómeno originadas en dos áreas de estudio, la Historia del Arte y la Historia de la Música, bien delimitadas, pero cuyos trabajos conjuntos suelen ser enormemente enriquecedores, por las numerosas conexiones epistemológicas e historiográficas existentes entre las dos disciplinas.

Si también morir es fiesta, las ceremonias fúnebres de reyes y reinas no podían estar exentas del brillo y boato propios de estas otras celebraciones lúdicas. Entre las múltiples manifestaciones plásticas y simbólicas de dolor y respeto expuestas por los cabildos destaca, sin ninguna duda, el túmulo que se erigía en iglesias y catedrales, máquina que aunaba las más excelsas artes para mostrar las virtudes del fallecido, que le hacían merecedor de la gloria y el dolor de los súbditos, como se puso de manifiesto en el que se erigió en la catedral de Sevilla en honor de M. ${ }^{a}$ Isabel de Braganza en 1819, estudiado por Rosario Camacho en
Archivo Hispalense ( $^{\circ}$ 52, 2000, pp. 37-49). Esta reina, que apenas vivió veintiún años, fue también protagonista de otro de sus textos (publicado en Luchas de género en el arte a través de la imagen, 2002, pp. 199-216, t. II) en el que hace un recorrido por su vida en la Corte, desde su llegada a Madrid, que la recibió engalanada con arcos y colgaduras, hasta su muerte, que acaeció dos años después, suceso que fue conmemorado en numerosas ciudades que Iloraron su pérdida levantando catafalcos, algunos de los cuales son analizados por la doctora Camacho.

En todas estas investigaciones la autora ha analizado con rigor, desde una visión interdisciplinar, los múltiples aspectos que encierran las celebraciones del pasado. Con una prosa exquisita envuelve al lector y lo traslada a un tiempo y a un espacio utópicos, en los que cualquier atisbo de pesadumbre o fatalidad queda enmascarada, al igual que la ciudad, que se presenta ante el pueblo en estos días festivos falsamente remozada.

"La fiesta es algo muy serio"; con esta frase hemos comenzado esta reseña, palabras que Rosario Camacho pronunció en 2007 en la presentación de la exposición "Fiesta y Simulacro». Cinco años después, también en septiembre, Rosario volvía a manifestar la importancia de la misma y de su estudio ante un numeroso grupo de alumnos e investigadores. $Y$ lo hacía en la 
inauguración del Seminario Internacional Fiestas y mecenazgo en las relaciones culturales del Mediterráneo en la Edad Moderna (20-22 de septiembre, 2012), que organizó en la UMA junto con Eduardo Asenjo y Belén Calderón, cuyas actas acaban de publicarse. Esta ha sido su última actividad universitaria, porque, lo sabemos, Charo se ha jubilado. El Diccionario de la Lengua Española define este término como "persona que ha dejado de trabajar». Sin embargo, para mujeres como ella se deberían barajar otros vocablos, porque su actividad profesional habrá cesado, pero no la investigadora; sigue asistiendo a jornadas y congresos, continúa "navegando" con entusiasmo entre documentos y libros en archivos y bibliotecas, nos sigue deleitando con sus conferencias y charlas, y prosigue incansable su labor en la Academia y en las múltiples comisiones a las que pertenece... y, por supuesto, seguirá acudiendo, con su habitual modestia, allí donde la llamen y sea necesaria.

\section{Rosario Camacho y la arquitectura malagueña del XIX}

Francisco García Gómez

Universidad de Málaga

Hay experiencias que, como alumno, nunca se olvidan, de igual modo que hay profesores que dejan una huella más profunda que otros. En mi caso, siempre recordaré aquel día de 1990 en que Rosario Camacho, en la asignatura Arte español de la Licenciatura de Geografía e Historia, nos llevó al grupo de cuarto curso de paseo por la Málaga del siglo XIX. Nunca hasta entonces ese importante pasado decimonónico de la ciudad se me había aparecido tan esclarecedor como cuando nos iba desentrañando casas, iglesias y edificios públicos con el conocimiento y la profundidad que siempre han caracterizado a la gran maestra del Departamento de Arte.

Si bien la principal especialidad de Rosario Camacho ha sido la arquitectura y la cultura del barroco en general, la versatilidad y la apertura de miras han sido dos de los rasgos definitorios de su labor investigadora. No hay más que ver esta sección del Boletín de Arte para darse cuenta de tal diversidad de intereses. $Y$ de entre estos temas "tangenciales" a los que siempre ha atendido más allá de lo barroco, se encuentran el urbanismo y la arquitectura de la Málaga del XIX. 